Artuklu International Journal of Health Sciences

journal homepage: https://www.artuklu.edu.tr/aijhs

\title{
Türkiye’nin Güneydoğu Bölgesinde Herediter Hemokromatoz Gen Mutasyonları
}

\section{Hereditary Hemochromatosis Gene Mutations in the South Eastern Region of Turkey}

\author{
Semir Paşa $\mathrm{a}^{\mathrm{a}^{*}}$ \\ a Mardin Artuklu Üniversitesi, Sağlık Bilimler Fakültesi, Mardin. ORCID: https://orcid.org/0000-0001-8029-7622 \\ "İletişimden sorumlu yazar, E-mail: semirpasa@artuklu.edu.tr
}

ARTICLE INFO

Article History:

Received 21.12.2021

Received in revised form 24.12.2021

Accepted 26.12.2021

Keywords:

Hereditary hemochromatosis

HFE gene mutation

Iron metabolism diseases

$\mathrm{C} 282 \mathrm{Y}$

H63D

\begin{abstract}
Hereditary hemochromatosis $(\mathrm{HH})$ is a common disorder of iron metabolism with autosomal recessive inheritance. Most affected patients are homozygous for the missense mutation which results in the substition of tyrosine for cysteine at amino acid 282(C282Y). A more common mutation is the substition of aspartat for histidine at amino acid 63 (H63D); this mutation may contribute to minor increases in iron levels but rarely iron overload in the absence of $\mathrm{C} 282 \mathrm{Y}$. Diagnosis of HH is usually based on a combination of various genetic or phenotypic criteria. We conducted a study to describe the $\mathrm{HH}$ mutations in the patients with high transferrine saturation, and with clinical suspicion or findings that attributed to HH. 19 of 97 patients $(19,5 \%)$ have heterozygous H63D mutations and no other mutation was detected. In our medical center all of the hemochromatosis cases are associated with secondary iron overload and no patient with $\mathrm{HH}$ was detected. The results of other population based studies in our country supporting our data however further population based studies are required to confirm this data in our region.
\end{abstract}

\section{MAKALE BILGIILERİ}

Makale Geçmişi:

Geliş Tarihi: 21.12.2021

Revizyon Tarihi: 24.12 .202

Kabul Tarihi: 26.12.2021

\section{Anahtar Kelimeler:}

Herediter hemokromatoz

HFE gen mutasyonu

Demir metabolizma hastalıkları

$\mathrm{C} 282 \mathrm{Y}$

H63D

\section{ÖZET}

Herediter hemokromatoz $(\mathrm{HH})$, otozomal resesif kalıtılan sık bir demir metabolizma bozukluğudur. Etkilenen bireylerin büyük kısmında 282. aminoasit pozisyonundaki tirozinin yerini sistein (C282Y) almıştır. Bir diğer sık mutasyon da 63. pozisyondaki aspartın yerine histidinin geldiği H63D mutasyonudur. Bu ikinci mutasyonda demir düzeylerinde daha hafif bir yükselme gözlenir ve C282Y mutasyonunun eşlik etmediği olgularda nadiren demir yüklenmesi klinik bulguları ortaya çıkmaktadır. HH tanısı genetik ve fenotipik özelliklerin birlikte değerlendirilmesi ile yapılmaktadır. Biz bu çalışmada yüksek transferrin satürasyonu olup klinik olarak HH düşünülen hastalarımızda HH gen mutasyonları sıklıkları ve dağılımlarını değerlendirmeyi amaçladık. Değerlendirdiğimiz 97 hastamızın 19'unda heterozigot H63D mutasyonu saptanırken baska diğer hastalarımızda herhangi bir mutasyon saptamadık. Merkezimize başuran tüm hemokromatoz hastaları sekonder demir yüklenmesi olgularında olusmaktaydı ve $\mathrm{HH}$ olgusuna hiç rastlamadık. Ülkemizde yapılan diğer toplum taraması çalışmaları da bulgularımızı destekler nitelikte olsa da bu mutasyonların sıklığı ve etkilerini değerlendirmek için daha geniş ölçekli çalışmalara ihtiyaç vardır.

C 2021 Mardin Artuklu Üniversitesi. Tüm hakları saklıdır.

\section{Giriş}

Vücutta aşırı miktarlarda biriken demir; karaciğer, pankreas, testisler, diğer endokrin organlar ve kalp başta olmak üzere çeşitli organ ve sistemlerde hasara yol açar. Hemokromatozis terimi, bütün demir birikim hastalıklarını kapsamakta ancak hastaların büyük kısmını sekonder nedenler, yani kan transfüzyonları, inefektif eritropoez nedenleri ve IV demir replasmanları oluşturmaktadır. Herhangi ikincil bir bozukluğu olmayan hasta grubuna ise primer veya herediter hemokromatozis $(\mathrm{HH})$ adı verilmektedir $(1,2)$. Bu tabloyu ilk inceleyen klinisyenlerden Fransız Trousseau ve Troisier 19. Yüzyılın ikinci yarısında nadir görülen deride koyulaşma, diyabet ve sirozun birlikte görüldüğ̈̈ bir hasta grubu tanımladılar. Bundan 30 yıl kadar sonra Alman patolog von Recklinghausen bu klinik tabloyu hämochromatose olarak adlandırmıştır. 1935 yılında Joseph Sheldon hemokromatozun klinik bulgularını taşıyan ve yayınlanmış 311 olgunun değerlendirmesinde bunun kalıtsal bir hastalık olabileceğini ifade etmiştir. 1996 ya gelindiğinde Feder ve arkadaşları HH'den sorumlu olduğu tespit edilen hemokromatoz geninin (HFE) iki major mutasyonu olan C282Y ve H63D'nin 6. kromozomda tespiti HH'nin major formlarının belirlenmesini sağladı. Daha sonraları yapılan toplum çalışmalarında HH'nin en 
yaygin formunun HFE'nin C282Y mutasyonu olduğu ve Kuzey Avrupa kökenlilerde yaklaşık olarak 1/250 sıklıkta görüldüğü saptanmıştır. Sonraki yıllarda devam eden çalışmalarda V53M, V59M, H63H, Q127H, Q283P, P168X, E168Q, E168X ve W169X gibi farklı HFE gen mutasyonları saptanmıştır (3-7).

HH tanısı genetik ve çeşitli klinik bulguların birlikteliği ile konulmaktadır. Genetik olarak HFE genindeki mutasyonlar taranırken klinik olarak da hastada karaciğer sirozu, hepatosellüler karsinom (HCC), diyabetes mellitus (DM) ve diğer endokrinopatiler, artropati, kardiyomyopati varlığı veya bunlar ortaya çıkmadan laboratuvar olarak saptanan yüksek transferrin satürasyonu (TS) ve ferritin düzeyleri ile tanı konulmaya çalışılmaktadır. Genetik olarak C282Y homozigot mutasyonu veya C282Y' nin H63D ile compound heterozigotluğu durumlarında HH ortaya çıkmaktadır. Bir diğer sık mutasyon olan S65C mutasyonu genellikle benign tablolar oluştururken diğer mutasyonlarla ilişkili tanımlanmış bir klinik tablo mevcut değildir $(1,6)$. Günümüzde HH için en güvenilir tanı yöntemi olarak kesin bir görüş birliği olmamasına rağmen TS ve serum ferritin düzeyi kullanılmaktadır. Yeni olarak da HFE mutasyonlarının keşfedilmesiyle, tarama yapılarak HH'nin klinik semptomları gelişmeden önce hastalığın saptanabilmesi mümkün olmuştur. 6 . kromozomda, HLA-A lokusunda bulunan bu gende sıklıkla C282Y ve/veya H63D mutasyonu saptanmaktadır. Toplumda HH'li hastalarda \%69-100 arasında C282Y homozigotluğu saptanır. HFE geninin görevi plazma membranında bulunan Transferrin reseptörü (Tfr) ile etkileşerek, Tfr'nin transferine olan afinitesini azaltmaktır. HFE mutant gen (C282Y) $\beta-2$ mikroglobulinle bağlanamaz. HFE- $\beta-2$ mikroglobulin kompleksi hücre membranında Tfr ile etkileşemez ve transferine olan ilgisini azaltamaz, sonuçta duodenumdan ve üst ince barsaktan fazla miktarda demir emilmesine neden olur. $\mathrm{HH}$ hastalarında doğumdan itibaren sürekli olarak bağırsaklardan uygunsuz olarak aşırı miktarda demir emilimi olmaktadır $(6,7)$.

Hemokromatozisten şüphelenilen hastaların tanısında öncelikle serum ferritin düzeyi ve açlık serum TS değerlendirilmelidir. Serum ferritin düzeyi alkolik karaciğer hastalığı, hepatit C enfeksiyonu, nonalkolik steatohepatit gibi bazı durumlarda da yükselebildiği gibi, bir akut faz reaktanı olarak enfeksiyonlarda veya neoplastik hastalıklarda da yükselebilmektedir. Ferritinin HH tanısı için spesifik olmaması, TS ile birlikte değerlendirilmesini gerektirmektedir. TS aşağıdaki formülle hesaplanabilir. TS $=100 \times$ serum demir konsantrasyonu / total demir bağlama kapasitesi. TS'nin \%45-50'nin üstünde olmas1 tanıda değerlidir. Serum ferritin düzeyi ve TS'nin birlikteliğinin HH tanısında negatif prediktif değeri \%97'dir (8-11).

Hastaların erken tanı alması ve flebotomiye uygun zamanda başlanılmasıyla siroz, HCC, artrit, DM ve diğer endokrin sisteme ait komplikasyonlar önlenebilir. Tedavideki amaç fazla olan demiri vücuttan atmaktır. Bunun için en sık flebotomi yöntemi kullanılır. Flebotomi siroz gelişmeden önce uygulanmaya başlanırsa HH'de mortalite ve morbiditeyi azaltır. Halsizlik, yorgunluk, deri pigmentasyonu, DM'deki insülin ihtiyacı ve karın ağrısı gibi klinik semptomlar flebotomi ile düzelebilirken, artralji, hipogonadizm, siroz gibi bulgularda iyileşme görülmeyebilir. HCC potansiyel hayatı tehdit edici bir komplikasyondur ve HH'de flebotomi yapılmasına rağmen bu hastalarda yaklaşık \%30 oranında ölüme neden olabilmektedir. Flebotomi haftada bir veya hastalar tolere edebilirse iki kez olacak şekilde uygulanabilir ve orta derecede demir eksikliği oluşturulmaya çalışılır. Bir kez yapılan flebotomi ile vücuttan yaklaşık $500 \mathrm{ml}$ kan ve $250 \mathrm{mg}$ demir uzaklaştırılmış olur. Yani vücuttan 1 gr demir atılması için 4 kez flebotomi yapılması gerekir. Her 1-2 gr demir uzaklaştırıldığında serum ferritin düzeyleri 2-3 ayda bir kontrol edilmelidir. Her kan almada hematokrit değerinde 10 birimlik ya da başlangıcın \%20'si kadar düşme olacak şekilde flebotomiye devam edilmesi gerekir. Serum ferritin düzeyi ve TS her 3 ayda bir kontrol edilmelidir. Flebotomi yaparken asıl hedefimiz serum ferritin düzeyini $<50 \mathrm{ng} / \mathrm{ml} \mathrm{nin}$, TS'nu ise \%50'nin altında tutmaktır. DM gelişmiş ise makro ve mikrovasküler komplikasyonları engellemek için hastaların insülinle tedavi edilmeleri gerekir. Artrit, artralji gibi şikayetler için analjezikler kullanılabilir. Hastalarda hipogonadotropik hipogonadizm gelişmiş ise hormon replasman tedavisi gerekli olabilir $(7,12$, $13)$.

Biz bu çalışmada ülkemizdeki HFE gen mutasyonlarının sıklığı ve coğrafi - farklı toplumsal gruplardaki dağılımı hakkındaki verilerin yetersizliğinden yola çıkarak, Güneydoğu Anadolu Bölgesinde klinik ve laboratuvar özellikleri açısından $\mathrm{HH}$ düşünülen hastalarda HFE gen mutasyonlarını araştırmayı, mutasyonların her biri için sıklık ve klinikopatolojik ilişkilerini değerlendirmeyi amaçladık.

\section{Hastalar ve Yöntem}

İç hastalıkları ve hematoloji polikliniklerimize çeşitli nedenlerle başvuran hastalarda artrit, karaciğer enzim yüksekliği, anemi ve polisitemilerin gibi demir metabolizma hastalığı düşünülen hastalardan: TS $=100 \mathrm{x}$ serum demir konsantrasyonu / total demir bağlama kapasitesi formülü ile hesaplanan TS \%38'in üzerinde 
olan hastalar takiplerde HFE gen mutasyon analizi ihtiyaci açısından değerlendirildi. Standart biyokimyasal yöntemlerle çalışılan alanin aminotransferaz (ALT), aspartat aminotransferaz (AST), alkalin fosfotaz (ALP), gamma glutamiltransferaz (GGT), total protein, albumin, ferritin (normal değer: kadın 11-306 $\mathrm{ng} / \mathrm{mL}$, erkek 23-336 ng/mL), serum demiri (normal değer: kadın 40-170 $\mu \mathrm{g} / \mathrm{dL}$, erkek 50-175 $\mu \mathrm{g} / \mathrm{dL}$ ), total demir bağlama kapasitesi (TDBK) (normal değer: 250-410 $\mu \mathrm{gr} / \mathrm{dL}$ ) değerleri tarandi.

Yüksek TS ve ferritin düzeyleri saptadığımız ve klinik olarak HH düşündüğümüz 97 hastada C282Y, Q283P, H 63D, and S65C, V53M, V59M, Q127H, P160delC, E168Q, E168X, W 169X, TFR2; E60X, M172K, Y250X, AVAQ594-597del, FPN1; $\mathrm{N} 144 \mathrm{H}, \mathrm{V} 162$ del mutasyon analizleri yaparak sonuçları değerlendirdik.

\subsection{Restriction Fragment Length Polimorfizim (RFLP) Analizi}

Genomik DNS EDTA içerikli kanda lenfositlerden elde edildi. HFE geni ekson 4'teki C282Y gen amplifikasyonu için ile mutasyon analizi için HFE fov primer 5'-TCC AGT CTT CCT GGC AA-3' ve HFE (4) rev primer 5' TTCTAGCTCCTGGCTCTCA-3' kullanıldı. Ekson 2'deki S65C geni amplifikasyonu ve mutasyon analizi için HFE primer fov 5'TGTGGAGCCTCAACATCCT-3' ve HFE rev 5'TGAAAAGCTCTGACAACCTCA-3' kullanıldı. PCR amplifikasyonunda total hacim $25 \mu \mathrm{l}$ (100 ng genomik DNA, her bir dNTP den $200 \mu \mathrm{M}$, her primerden $200 \mathrm{nM}, 1.0 \mathrm{mM} \mathrm{MgCl} 2$ 10× PCR buffer solüsyonu ve $2.5 \mathrm{U}$ Taq polymerase kullanıldı. Önce $95^{\circ} \mathrm{C}$ de 5 dakika, sonrasında 30 siklus halinde $95^{\circ} \mathrm{C}$ de 30 saniyelik, devamında $56{ }^{\circ} \mathrm{C}$ de 30 saniye inkübasyon, son olarak da $72{ }^{\circ} \mathrm{C}$ de 10 dakika inbübasyon ile PCR amplifikasyon işlemi uygulandi. Restriksiyon reaksiyonu için $2.5 \mathrm{U}$ BcII (codon 63), HinfI (codon 65) veya Rsa I (codon 282) ve tampon toplam $10 \mu \mathrm{l}$ olacak şekilde kullanıldı. Örnekler 2 saat süre ile Bcll restriksiyon için $50^{\circ} \mathrm{C}$ de, Hinfl ve RsaI restriksiyonu için $37^{\circ} \mathrm{C}$ de inkübasyona birakıldı. Restriction Fragment Length Polimorfizim analiz sonuçları DNA sekans analizi ile konfirme edildi (3100 ABIPrism Genetic Analyzer - Applied Biosystems, Foster City, CA, USA).

\section{Bulgular}

Hastalarda ortalama ferritin düzeyi $285 \mathrm{ng} / \mathrm{mL}$ (196-1936 ng/mL aralığında) saptandı. 70 hastanın TS \%38-45 aralığında; kalan 27 hastanın ise \%45-50 aralığında saptandı. Toplam 97 hastanın 19'unda $(\% 19,5)$ heterozigot H63D mutasyonu saptanırken diğer mutasyonlardan hiçbiri saptanmadi.

H63D mutasyonu saptanan 19 hastanın 14 tanesi (\%20) TS \%3845 arası olan grupta yer alırken, 5 tanesi $(\% 18,5)$ TS $>45$ olan grupta idi. Bu iki grup hasta açısından hematokromatoz ilişkili herhangi bir yakınma açısından fark olmadığı gibi mutasyonun dağılım sıkılığı açısından da anlamlı bir fark saptanmadı.

Hastalarımız içinde her iki grup arasında laboratuvar değerlerinden karaciğer fonksiyon testleri, bilirübinler, koagülasyon testleri, albümin ve hemogram parametreleri ile artrit, kronik karaciğer hastalığı, kalp yetersizliği veya endokrinopati gibi klinik bulgular açısından da anlamlı bir farklılık saptanmadı. Karaciğer enzim yüksekliği saptanan iki hasta biyopsi ile değerlendirildi ve karaciğerde demir yüklenmesi bulguları saptand1. Bu hastalardan biri H63D mutasyonuna sahip iken diğerinde mutasyon yoktu ve her ikisi de TS \%45 in altında olan gruptaydı. Bu sonuçlar ülkemizde yapılan diğer toplum taraması çalışmaları ile benzerlik göstermektedir.

\section{Tartışma ve Sonuç}

Farklı ülkeler ve farklı topluluklarda HFE gen mutasyon analizleri ve allel frekanslarının saptanması her ülke için demir yüklenmesi hastalıklarıyla ne sıklıkta karşılaşacağımızın saptanması, tarama testleri yapılması ve gerekli tedavilerin başlanabilmesi, elde edilecek sonuçların öngörülebilmesi açısından oldukça önemlidir. Bu analizler aynı zamanda geçmiş yıllardaki toplumsal göçler ve kökenlere dair araştırmalara da yol gösterici olabilir.

C282Y mutasyonu, Kuzey Avrupa kökenlilerde görülen en yaygın HFE gen mutasyonudur. Avrupa'da kuzeyden güneye doğru görülme sıklığında azalma görülmektedir. $\mathrm{Bu}$ bulgu genetik aktarımın dünyaya da Kuzey Avrupa'dan dağıldığını düşündürmektedir. $\mathrm{Bu}$ mutasyonun sıklığının araştırıldığı bir meta-analizde 63 ayrı Avrupa popülasyonundan oluşan 10,708 akraba olmayan kişide HH'nin Avrupa'daki major sebebinin bu mutasyon olduğu vurgulanmakta ve sıklığının doğuya ve kuzeye gittikçe azaldığı gösterilmektedir. H63D mutasyonu dünya genelinde daha yaygın görülen bir mutasyondur. Klinik etkisi daha zayıf olmakla birlikte homozigot veya $\mathrm{C} 282 \mathrm{Y}$ ile compound heterozigot mutasyonunun, HH riskini arttırdığı bildirilmektedir (7, 14). Türkiye'de HFE gen mutasyonu çalışmaları çok azdır. Yapılan birkaç çalışmada H63D mutasyonuna rastlanmış, fakat C282Y bulunmamıştır (15-19). Ülkemizde C282Y taşıyan ilk aile 2007'de Yönal ve arkadaşları (18) tarafindan İstanbul'dan rapor edilmiştir. 2014'te Aydınol ve arkadaşları (20) tarafından 
Diyarbakır yöresinde aile içi evliliklerin çok olduğu bir köyde yoğun HFE gen mutasyonu taşıyan geniş bir aile odağı ortaya çıkarılmıştır. $\mathrm{Bu}$ ailede hastaneye müracaat eden bir $\mathrm{C} 282 \mathrm{Y}$ homozigot mutasyon saptanan hastanın akrabalarından, 17 kişide C282Y heterozigot mutasyonu, 4 vakada H63D heterozigot mutasyonu, 2 vakada ise $\mathrm{C} 282 \mathrm{Y}$ homozigot mutasyon bulunmuştur. Ülkemizden Şimşek ve arkadaşları (15) tarafından yayınlanan çalışmada ise TS \%45'in üzerinde olan 86 birey (hasta grubu) taranmış, TS 45'in altında olan 57 birey (kontrol grubu) ile karşılaştırılmıştır. Hiçbir hastada C282Y mutasyonu saptanmazken; H63D mutasyonu ise hasta grubunda \%27, kontrol grubunda \%21 olarak bulunmuş ve arada istatistiksel fark saptanmamış olması klinik tablo ile ilişkili olmadığ 1 sonucunu desteklemiştir.

Biz de bu çalışmamızda Güneydoğu Anadolu Bölgesinde merkezimize başvuran hastalarda yaptığımız bu çalışmada hemokromatoz bulguları saptanan, klinik ve laboratuvar olarak uyumlu olabilecek olgularımızda mutasyon analizleri yaptık. Yaptığımız değerlendirmede hemokromatoz bulgularının sekonder demir yüklenmesine bağlı ortaya çıktığını ve herediter hiçbir hastamız olmadığını gördük. Benzer coğrafyada kapalı bir aile yapısında saptanmış olan $\mathrm{C} 282 \mathrm{Y}$ mutasyonlarının aile dışında başka hiç kimsede saptanmamış olması oldukça şaşırtıcı idi. Her ne kadar H63D heterozigot mutasyonları çalışma grubumuzda sık olarak saptanmış olsa da bu mutasyon demir yüklenmesi hastalıkları ile sıkı bir ilişki içinde değildir. Elde ettiğimiz sonuç ülkemizden yayınlanmış diğer çalışmalar ile benzerlik göstermektedir. Hatta biz bu çalışmada daha fazla hasta tarayabilmiş olmak amacı ile daha önceki çalışmalardan farklı olarak sadece TS \%45'in üzerinde olan hastaları değil, TS \%38 üzerinde olan tüm başvurularda mutasyon analizi yaparak riskli mutasyon taşıyan hasta bulabileceğimizi düşündük. Gen polimorfiziminin etnik ve irksal farklılıkları ve ülkemizde tarihsel geçmişte farklı pek çok etnik toplulukların varlı̆̆ 1 da düşünüldüğünde gen havuzumuzun oldukça zengin olduğu ve bu çeşitlilik nedeni ile daha geniş ve farklı yörelerde benzer çalışmaların yapılması gereklidir.

Sonuç olarak biz bu çalışmamızda HFE gen mutasyonlarının çalışma grubumuzda yaygın olmadığı, Kuzey Avrupa'da herediter hemokromatoz olgularında siklikla saptanan C282Y mutasyonunun hiç görülmediğini, klinik yansımaları olmayan H63D mutasyonunun görülse de hemokromatoz ile ilişkili olmadığını, çalışma grubumuzdaki demir yüklenmesi kliniği olan hastaların tümünde sekonder nedenlere bağlı klinik bulgular oluştuğunu saptadık. Buna rağmen ülkemiz kaynaklı bazı çalışmalarda $\mathrm{C} 282 \mathrm{Y}$ mutasyonu gösterilmiş olması nedeni ile yüksek TS sahip demir yüklenmesi hastalarında mutasyon analizi yapmanın yine de gerekebileceği ve saptanan mutasyonlar olursa aile taraması yapılması önerilebilir.

Çıkar Çatışması: Çalışmada herhangi bir çıkar çatışması yoktur.

Finansal Destek: Bu makalede herhangi bir finansal destek alınmamıştır.

Etik Kurul Onayı: Transferrin satürasyonu yüksek hemokromatoz düşünülen hasta grubunda mevcut bilimsel verileri ışı̆̆ında genetik mutasyon araştırılması mutlak endikedir. $\mathrm{Bu}$ doğrultuda sosyal güvenlik kurumu tarafindan da bedeli ödenerek yapılmış bu tetkiklerin retrospektif değerlendirmesinin kaleme alındığı bu çalışmada etik kurul onayı gerekmemektedir.

\section{Kaynaklar}

1. Aslan M. Demir birikimi olan hastada C282y/H63d mutasyonu: Herediter hemokromatozis olgusu. Turk Klinik Biyokimya Derg. 2013; 11(1): 31-5.

2. Bacon BR, Britton RS. Hemochromatosis. In: Feldman Mark, ed. Gastrointestinal and liver diseases pathophysiology, diagnosis, management. 8th ed. Canada: Saunders Elsevier, 2006: 1589-99.

3. Beutler E. Hemochromatosis: genetics and pathophysiology. Annu Rev Med. 2006; $57: 331-47$

4. Bacon BR, Powell LW, Adams PC, Kresina TF, Hoofnagle JH. Molecular medicine and hemochromatosis: At the crossroads. Gastroenterology. 1999; 116: 193-207.

5. Beutler E. Hemochromatosis: genetics and pathophysiology. Annu Rev Med. 2006; 57: 331-47.

6. Tuzun Y, Yakut M, Dursun M, Bayan K, Yilmaz S, Batun S. Kriptojenik ve HBV ilișkili sirozda HFE gen mutasyonları. Akademik Gastroenteroloji Dergisi. 8 (2), 6973.

7. Bayram Y, Turkay C. Herediter Hemokromatozis tanı ve Tedavi. Güncel Gastroenteroloji. 14 (2), 76-83.

8. Di Bisceglie AM, Axiostis CA, Hoofnagle JH, Bacon BR. Measurament of iron status in patients with chronic hepatitis. Gastroenterology. 1992; 102: 2108-13.

9. Chapman RW, Morgan MY, Laulict M, Hoffbrand AV, Sherlock S. Hepatic iron stores and markers of iron overload in alcoholics and patients with idyopathic haemochromatosis. Dig Dis Sci. 1982; 27: 909-16.

10. Mac Cullen MA, Crawford DH, Hickman PE. Screening for haemochromatosis. Clin Chim Acta. 2002; 315: 169-86.

11. Basset ML, Halliday JW, Ferris RA, Powell LW. Diagnosis of haemochromatosis in young subjects: Predictive accuracy of biochemical screening tests. Gastroenterolgy. 1984; 87: 628-33.

12. Niederau C, Fischer R, Purschel A, Stremmel W, Haussinger D, Strohmeyer G. Long term survival in patients with hereditary haemochromatosis. Gastroenterology. 1996; 110(4): 1107-19.

13. Tavill AS. Diagnosis and management of haemochromatosis. AASLD Practice Guidelines. Hepatology. 2001; 33: 1321-8.

14. Olynyk JK, Cullen DJ, Aquilia S, Rossi E, Summerville L, Powell LW. A populaion-based study of the clinical expression of the haemochromatosis gene. $\mathrm{N}$ Engl J Med. 1999; 341:718-24 
15. Şimşek H, Sumer H, Yilmaz E, Balaban YH, Özcebe O, Hasçelik G, et al. Frequency of HFE Mutations among Turkish blood donors according to transferin saturation: genotype screening for hereditary hemochromatosis among voluntary blood donors in Turkey. J Clin Gastroenterol.. 2004; 38(8): 671-5.

16. Şimşek H, Balaban YH, Yilmaz E,Sümer H, Büyükaşık,Y, Cengiz C, et al. Mutations of the HFE gene among Turkish hereditary hemochromatosis patients. Ann Hematol. 2005; 84(10): 646-9.

17. Yönal O, Hatırnaz Ö, Akyüz F, Özbek U, Demir K, Kaymakoğlu S, et al. HFE mutation, Chronic Liver Disease, and Iron Overload in Turkey. DigDis Sci. 2007; 52:3298- 3302 .

18. Yönal O, Hatırnaz Ö, Akyüz F, Köroglu G, Özbek U, Cefle K, Mungan Z. Definition of $\mathrm{C} 282 \mathrm{Y}$ mutation in a hereditary hemochromatosis family from Turkey. TurkJ Gastroenterol. 2007; 18(1) 53-7.

19. Bozkaya H, Bektas M, Metin O, Erkan O, İbrahimoğlu D, Dalva K, et al. Screening for hemochromatosis in Turkey. Dig Dis Sci. 2004; 49: 444-9.

20. Aydınol B, Yılmaz S, Genç S, Aydınol MM. HFE geninde, C282Y homozigot mutasyonu saptanan bir olgu takdimi ve bu nedenle ailesinde HFE gen mutasyonu sıklığı. Turk J Biochem 2014; 39 (2) ; 150-154. 